in the Kiev province of Cherkasy county of Ternovka village, the landowners of retired second lieutenant Alexander and the guard and the headquarters of captain Vladislav Krestyanovs Grevs consisting of men and women of the yard people and peasants]. Derzhavnyi arkhiv Kyivskoi oblasti. F. 280. Kyivska kazenna palata. Op. 2. Spr. 687.

21. Serdiuk, I. O. (2008). Osoblyvosti vidobrazhennia vikovykh katehorii naselennia Livoberezhnoi Ukrainy v Rumiantsevskomu opysi Malorosii [Peculiarities of the image of the age-old population category of the Liberated Ukraine in the Rumyantsevsky description Serdyuk]. Visnyk Cherkaskoho universytetu. Seriia «Istorychni nauky», № 33-34.

22. Troytskaia, Y. (1995). Revizii naseleniia Rossii kak istochnik demohraficheskoi informatsii (metodolohicheskiye problemy) [Revision of the population of Russia as a source of demographic information (methodological problems)]: dys. kand. ekon. nauk. Moskva.

УДК 94:669-057.21](477.7) «18» (092)

\title{
РОЛЬ ІНЖЕНЕРНО-ТЕХНІЧНОЇ ІНТЕЛІГЕНЦІЇ В СТАНОВЛЕННІ ТА РОЗВИТКУ ПРОМИСЛОВОСТІ ПІВДНЯ УКРАЇНИ МОДЕРНОЇ ДОБИ
}

\section{Довжук Ігор}

Мета статті - розглянути професійну діяльність гірничих інженерів та інших профільних фахівиів на Півдні Украӥни в модерну добу та показати їхню роль у становленні й розвитку тут металургійної промисловості.

Видатний гірничий інженер А. Ф. Мевіус присвятив майже півстоліття свого життя розвитку металургії Донечького басейну. Він багато років пропрацював у Луганському гірничому окрузі, начальником якого був з 1861 р. Працюючи на цій посадi, він зробив багато корисного для розвитку гірничо-металургійного виробництва в Донбасі. У 1860-ті роки керував будівництвом периої в Украӥні пудлінгової фабрики Луганського ливарного заводу. А. Ф. Мевіус - один з ініціаторів скликання з '̈здів гірничопромисловців Півдня Росії, які відіграли провідну роль у створенні промисловості Донбасу і Придніпров'я. Протягом 20 років він керував виконавчим органом з '̈здів - иого радою, користуючись авторитетом серед гірничих спеціалістів і промисловців Півдня.

Інженерно-технічна інтелігенція відіграла значну роль у становленні та розвитку залізорудної і металургійної промисловості Півдня у перед- $і$ післяреформений період. Інженери $i$ техніки спрямовували свою діяльність на вдосконалення виробництва та вивчення надр промислового регіону України. Відкриті інженерами великі поклади залізних руд стали базою для бурхливого розвитку тут металургійної промисловості. Технічні нововведення, упроваджені за ініціативою інженерно-технічних працівників, сприяли зростанню продуктивності виробництва. Окрім виробничої діяльності інженери займалися науковими дослідженнями, 
сприяючи розвитку теорії та практики гірничозаводської справи. Розглянута тема має перспективи подальшого дослідження, зокрема в період кіния XIX-nочатку XX cm., коли відбувався бурхливий індустріальний розвиток Російської імперії, зокрема. й України.

Ключові слова: Південь України, Донбас, залізорудна промисловість, металургійна промисловість, гірничі інженери.

У пореформений період, в умовах швидкого розвитку промисловості й зростання внутрішнього ринку в Російській імперії, і в Україні також, виник великий дефіцит металу. Гостро постало питання створення чорної металургії на мінеральному паливі, яка змогла б забезпечити високі темпи зростання виплавки металу. На той час основним районом, де економіко-географічні умови давали змогу створити металургійну базу на мінеральному паливі, був Південь України.

Цю проблему так чи інакше розглядали у своїх працях I. Фелькнер, I. Тіме, В. Сапальський, П. Фомін та ін. Мета цієї розвідки - розглянути професійну діяльність гірничих інженерів та інших профільних фахівців на Півдні України в перед- і післяреформений період та показати їхню роль у становленні й розвитку тут металургійної промисловості.

Луганський ливарний завод, що почав працювати з 1799 р., відіграв помітну роль у розвитку металургійної і залізорудної промисловості Півдня України. На базі підприємства багато років працювали вчені комісії та адміністративні органи, що вивчали поклади залізної руди і вугілля Донбасу. На кошти підприємства розвідали понад 20 залізорудних родовищ. До початку 40-х рр. ХІХ ст. 3 13 родовищ провели дослідні плавки [6, 24].

Інженерно-технічні працівники цього підприємства мали глибокі знання гірничої справи. Вони спрямовували свою діяльність на вдосконалення виробництва та вивчення надр Донбасу. Заводські інженери відкрили й дослідили десятки кам'яновугільних і залізорудних родовищ не тільки в Донбасі, але й в інших регіонах Російської імперії, сприяли розвитку теорії і практики гірничозаводської справи. Тут виросло багато талановитих спеціалістів, майстрів-самоуків, які залишили свій слід в історії Донбасу, серед них В. Черепанцев - творець однієї з перших у Російській імперії парових машин; механік заводу Л. Із'юров, який сконструював декілька верстатів, майстер ливарної справи М. Бєлоусов. Добрими спеціалістами, справжніми вмільцями зарекомендували себе гірничі інженери Сергій, Лев, Петро, Андрій і Михайло Шостаки, Іван Васильович Ільїн, Микола Миколайович Теплов, Олександр Борисович Іваницький (1811-1872) та інші, які поряд з виробничою діяльністю багато сил віддавали дослідженню надр Донбасу. Розвідці корисних копалин присвятили себе гірничі інженери П. Кульшин, С. Копанєв, Я. Колесников та ін. [8, 77].

Одночасно з вивченням і дослідними розробками залізорудних родовищ у Донецькому регіоні за рахунок казни гірничими інженерами проводилися роз- 
відки в інших районах Півдня, зокрема у Криворіжжі. У 1803 р. такі розвідки поблизу Кривого Рогу здійснив В. Пиленко. Ним були виявлені залізні руди вздовж річки Кам’янки і поблизу Кривого Рогу, берегом Інгульця та поблизу села Шестерні $[6,27]$. У 1835-1837 pр. чиновник гірничого департаменту П. Кульшин поблизу Кривого Рогу також знайшов родовища залізної руди $[15,456]$.

Увагу уряду привертали також корисні копалини Керченського півострова. У $30-\mathrm{x}$ рр. XIX ст. в районі Керчі гірничі інженери розпочали розвідувальні роботи родовищ залізних руд з метою організації тут металургійного виробництва. Інженери Микола Іванович Воскобойников (1803 - після 1846) та Олексій Васильович Гур'єв були направлені до Криму і на Тамань для докладного вивчення цих покладів. Вони виявили виходи бурих залізняків потужністю майже метр. У 1845 р. за розпорядженням Міністерства фінансів розвідки у Криму продовжували Гур'єв та Іваницький. Гур'єв вважав цілком можливим будівництво металургійного підприємства на керченських рудах і донецькому вугіллі.

Після відкриття потужного керченського залізорудного родовища й невдалих плавок чавуну на Луганському ливарному заводі подальше випробування руд на Півдні перенесли на Керченське металургійне підприємство, що почало працювати у травні 1850 р. Для нового підприємства у 1846 р. видобули майже 170 тис. пудів керченської руди. Проте його доменна піч працювала зі значними перебоями. Як з'ясувалося згодом, основною причиною цього була мала потужність повітродувної машини. Для проведення дослідів Гірничий учений комітет 18 травня 1851 р. вирішив відрядити до Керчі А. Мевіуса, який був добре знайомий з процесом доменного виробництва $[8,116]$.

Зазначимо, що Аполлон Федорович Мевіус (1820-1898) походив з роду металургів. Після закінчення у 1842 р. Петербурзького корпусу гірничих інженерів він кілька років працював на Уралі, де був керівником Златоустівського металургійного заводу [7, 322]. У 1848 р. А. Мевіус відвідав Францію, де ознайомився з передовими технологіями в галузі металургії, перевів на російську мову книгу з металургії Флєша, Барро і Потьє «Курс металлургии чугуна и железа». У 1851 р. його відрядили до Керчі для дослідження можливості виплавки чавуну з місцевих руд.

На заводі інженеру А. Мевіусу вдалося з'ясувати, що неполадки в роботі доменної печі обумовлювалися недостатньою кількістю повітря, що подавалося в домну. Під його керівництвом і за його участю спроєктували та побудували експериментальну домну менших розмірів (висотою 6 м), що дозволило ефективно використовувати наявну повітродувку. А. Мевіус з успіхом працював над вирішенням складної проблеми виплавки чавуну з керченських руд, досягнувши в цьому питанні позитивних результатів. Він відкрив нові родовища залізної 
руди, з якої одержав чавун досить високої якості. Цим була доведена можливість виплавки металу з керченських руд на донецькому паливі.

Окрім доменної печі, інженером А. Мевіусом у Керчі були побудовані пудлінгові печі. Це дало можливість отриманий чавун переробляти в залізо. Пудлінгові печі працювали на генераторному газі. Для металургійного виробництва Півдня це була важлива технічна новинка того часу. У Керчі Аполлон Федорович (де він перебував 3 дружиною і де народилося четверо дітей) пише одну 3 головних своїх книг «Чугунолитейное производство», в якій узагальнює вітчизняний і зарубіжний досвід отримання відливок, докладно розглядає і науково пояснює процеси складної ливарної технології. Ця книга була першим навчальним посібником 3 ливарного виробництва в Російській імперії ${ }^{1}$ [2, 311-312].

Керченський металургійний завод не був прибутковим підприємством через велику собівартість вугілля, привезеного гужовим транспортом. Техніку доменного виробництва на заводі освоювали дуже повільно, а вихід чавуну із сировиною становив лише $26 \%[12,14]$. Керченський металургійний завод проіснував недовго. У 1855 р., під час Кримської війни, побудований там завод було зруйновано. Інженер А. Мевіус переведений у Луганський гірничий округ.

У роки Кримської війни, а також після закінчення воєнних дій потреба в металі значно зросла. Це змушувало імперський уряд вжити заходів для створення на Півдні металургійних підприємств, паливної і залізорудної бази. Отож розвідки корисних копалин продовжувалися, зверталася особлива увага на Донецький басейн.

У 1856 р. гірниче відомство направило в Донецький басейн інженерів А. Носова і В. Сапальського 2 для проведення розвідок залізних руд і кам'яного вугілля - необхідних складових для функціонування нового металургійного заводу. Їм доручили також обрати місце для нового підприємства. Керівництво роботами поклали на гірничого інженера А. Мевіуса. За завданням Гірничого департаменту він розробив проєкт будівництва металургійного заводу на березі річки Садки у Бахмутському повіті, неподалік від сіл Софіївки та Роздольного у межах сучасного м. Снакієве $[8,118]$.

У 1857 р. А. Мевіуса відрядили до Німеччини і Бельгії для ознайомлення із сучасним станом чавуноливарного й залізоробного виробництва, а також розміщення замовлень у цих країнах на виготовлення обладнання для майбутнього

\footnotetext{
${ }^{1}$ Гірничий Учений комітет у 1854 р. схвалив монографію А. Мевіуса і виділив кошти на ії видання. Однак у травні 1855 р. під час Кримської війни турецькі війська захопили Керч і зруйнували побудований там металургійний завод. У загальному сум'ятті в Керченській типографії загубився рукопис книги. Після прибуття на Луганський завод Аполлон Федорович заново пише свою книгу, яка в 1857 р. була завершена й 1859 р. надрукована в типографії Харківського університету. У 1860 р. ця праця була удостоєна Демидівської премії 2-го ступеня Імператорської Санкт-Петербурзької академії наук.

${ }^{2}$ Сапальський Вікентій Францевич (1822 - не раніше 1883) - гірничий інженер.
} 
чавуноливарного заводу. Після повернення 3-за кордону А. Мевіуса призначено керівником будівництва цього заводу.

Будівництво заводу, який назвали Петровським, розпочали у 1858 р. На його будівництво уряд асигнував 220 тис. руб., а у 1860 р. додатково ще 53 тис. руб. Підприємству відвели 100 десятин землі й надали право добувати залізну руду на землях державних селян (за пуд руди платили 0,25 коп. і по 53 коп. $з$ кожної десятини землі, зайнятої гірничими роботами). Петровський завод був забезпечений значними запасами залізних руд (260 тис. пудів) з 19 родовищ $[5,171]$.

Розвідку залізних руд проводив В. Сапальський. Він розвідав руди двох типів $з$ таких родовищ: а) гніздові - стильські та каракубські, б) шаровидно-гніздові - софіївські, буєракські, микитівські, скотоватські, городищенські, корсунські, залізнянські, булавинські та ін. Поклади сировини були розміщені на відстані від 5 до 18 верст від заводу. Вміст заліза в руді переважно становив близько $40 \%$, але траплявся і 18-20\%. Окрім залізних руд новий завод потрібно було забезпечити кам'яним вугіллям, флюсовими, вогнетривкими і будівельними матеріалами. Гірничим інженером А. Мевіусом були зібрані проби для досліджень і випробувань та направлені в лабораторію департаменту гірничих і соляних справ. Там у 1861 р. ї дослідив Н. Іванов $[10,474]$.

Назарій Андрійович Іванов (1816-1883), який очолював лабораторію 3 1852 р. і керував ії роботами до 1872 р., сам неодноразово бував у Донецькому басейні з метою вивчення мінеральної сировини Луганського округу. У 1860 р. департамент гірничих і соляних справ звернувся до штабу Корпусу гірничих інженерів 3 проханням відрядити полковника Н. Іванова в Луганський округ на чотири місяці для визначення хімічного складу руд, флюсів і кам'яного вугілля, що заготовляються для чавуноплавильного заводу в Бахмутському повіті Луганського округу.

На момент прибуття Н. Іванова на Петровський завод там накопичилося багато руди із софіївського, микитівського, стильського, буєракського, корсунського, городищенського та інших родовищ. Ці руди, окрім микитівських, належать до бурих, або глинястих залізняків з великим або трохи меншим вмістом кремнезему. Середній вміст заліза в рудах - до 46-47 \%, кремнезему - від 6 до $13 \%$. Як флюс Іванов рекомендував використовувати вапняки, виходи яких зустрічаються в Донецькому басейні майже повсюди. Ще у 1858 р. для забезпечення заводу паливом було засновано Софіївський кам'яновугільний рудник. У 1862 р. на ньому видобули 156 тис. пудів вугілля, а у 1864 р. - 225 тис. пудів $[8,119]$.

На Півдні України потреба в металі постійно зростала, і на Петровський завод покладалися великі надії. Проте він так і не став центром південної металургійної промисловості, що зароджувалась. Однак перші дослідні плавки на 
мінеральному паливі тут не вдалися. Основна причина невдач була в неправильній конструкції доменної печі системи російського металурга Володимира Карловича Рашета (1812-1880). Обіймаючи посаду директора Гірничого департаменту (1863-1876 pp.), В. Рашет посилено втілював у виробництво винайдену ним доменну піч і вперше випробував ії роботу на Петровському заводі, проте ця піч виявилася непридатною для доменної плавки $[5,173]$.

Будівництво доменної печі на Петровському заводі закінчили на початку 1862 р., у квітні домну завантажили коксом ${ }^{3}$ і шихтою ${ }^{4}$. У лабораторії департаменту гірничих і соляних справ під керівництвом Н. Іванова провели аналізи руд і флюсового вапняку з метою визначення оптимального складу доменної шихти. Проте постійно ставалися неполадки та зупинки доменної печі, через що в 1864-1865 pр. завод не працював. 22 січня 1866 р. на Петровському заводі вперше одержали чавун достатньої якості. На середину лютого доменна піч дала 4318 пудів чавуну [11,38]. Хоча потім плавку припинили через несправність домни, усе-таки цей факт свідчив про придатність руд і вугілля Донбасу для металургійного виробництва.

Значну роль у налагодженні доменної плавки на мінеральному паливі відіграв гірничий інженер А. Мевіус, для якого Петровський завод став творчою лабораторією. За ініціативою Аполлона Федоровича на заводі впроваджено низку технічних нововведень. Наприклад, він уперше запропонував використовувати коксові гази для нагріву парових котлів, а також уловлювати доменний газ та нагрівати ним повітронагрівачі. Уперше в Російській імперії застосовано механічні виштовхувачі для звільнення коксових печей та гідравлічні підйомники для подачі шихти на колошник печі. Нововведенням у доменному виробництві було проведення систематичного хімічного аналізу завантаженої шихти та отриманих 3 неї чавуну і шлаків, що мало велике значення для підвищення якості металу, який виплавлявся $[1,119]$.

У 1866 р. царський уряд припинив фінансування Петровського заводу і його закрили. Незважаючи на нетривалість існування цього підприємства, його роль у створенні південноукраїнської металургійної промисловості $є$ вагомою. Інженерно-технічні працівники заводу, а також технічні спеціалісти, які працювали за його межами, зробили значний внесок у розвиток промисловості Півдня України. У зв'язку з будівництвом заводу в його околицях гірничі інженери провели розвідки і хімічні випробування залізних руд, кам'яного вугілля, флюсів і вогнетривких матеріалів. За участю гірничого інженера А. Мевіуса на Петровському заводі отримали перший чавун на мінеральному паливі.

\footnotetext{
${ }^{3}$ Кокс - вид твердого палива, яке одержують нагріванням кам'яного вугілля, торфу до високих температур без доступу повітря.

${ }^{4}$ Шихта - суміш матеріалів у певній пропорції (рудні концентрати, флюси тощо), призначена для переробки в металургійних печах.
} 
Зазначимо, що видатний гірничий інженер А. Мевіус присвятив майже півстоліття свого життя розвитку металургії Донецького басейну. Він багато років пропрацював у Луганському гірничому окрузі, начальником якого був з 1861 р. Перебуваючи на цій посаді, він зробив багато корисного для розвитку гірничометалургійного виробництва на Донбасі. У 1860-ті рр. керував будівництвом першої в Україні пудлінгової фабрики Луганського ливарного заводу. А. Мевіус один з ініціаторів скликання з'їдів гірничопромисловців Півдня Росії, які відіграли провідну роль у створенні промисловості Донбасу і Придніпров'я. Протягом 20 років він керував виконавчим органом з'їздів - його радою, користуючись авторитетом серед гірничих спеціалістів і промисловців Півдня. У 1887 р. А. Мевіуса призначили викладачем металургії на механічне відділення Харківського технологічного інституту, де він став першим завідувачем кафедри металургії чавуну і сталі в Україні. Окрім викладацької діяльності, він також займався редагуванням журналу «Горнозаводской листок».

А. Мевіус - автор близько 100 друкованих праць, серед яких: «Курс чугунолитейного производства» (1859р.), «Будущность горнозаводского промысла на Юге России» (1867р.), «Учебный курс металлургии чугуна, железа и стали» (1894 р.) - перший підручник з металургії, виданий в Україні, «Технический французско-русский словарь» на 64 тис. слів (1898р.), над яким гірничий інженер працював останні 28 років свого життя, та багато інших. За «відмінну, корисну та старанну службу» Аполлон Федорович нагороджений орденом св. Станіслава 2-го ступеня [1, 123-130].

Після закриття Петровського заводу Гірничий департамент зробив ще одну спробу освоїти виплавку чавуну з місцевих руд і вугілля. У 1866 р. уряд розпочав будівництво Лисичанського чавуноливарного заводу. Місце для нього було обрано в Лисичій Балці на правому березі Сіверського Дінця, за 80 км на північ від Луганського заводу. Ініціатива у виборі місця будівництва заводу належала В. К. Рашету, тодішньому директору Гірничого департаменту [9, 53].

Улітку 1867 р. Вчений комітет Гірничого департаменту відрядив Н. Іванова в Донецький басейн для огляду мінеральних родовищ та відбору проб залізних руд, різних сортів лисичанського вугілля, вапняків і вогнетривких глин для випробування в лабораторії департаменту гірничих і соляних справ. Усі обстежені ним родовища мінеральної сировини Назарій Андрійович наніс на карту і склав таблицю результатів хімічних аналізів [3, 220-232]. Тут він використав дані геологічних досліджень гірничих інженерів Анемподиста Олексійовича Носова й Олександра Олексійовича Носова, які проводили з 1864 р. по 1869 р. інструментальну геологічну зйомку в західній частині Донецького басейну. Н. А. Іванов позначив 19 родовищ бурих залізняків, що розташовувалися навколо 
заводу по берегах річок Сіверський Донець, Корсунь, Лозова, Лугань, по балках Часів Яр, Бахмутська, Сокорова, Соломенна та інших на відстані від 10 до 60 верст від заводу. У лабораторії департаменту гірничих і соляних справ Н. Івановим проведені хімічні аналізи руд і встановлено, що середній вміст заліза в родовищах сягав 26-59\% [5, 175].

Будівництво Лисичанського заводу завершили в 1870 р. Тут працювали в різний час гірничі інженери І. Фелькнер, М. Мещерін, М. Летуновський і С. Подимовський під загальним керівництвом начальника Луганського заводу Іліодора Федоровича Фелькнера (1829-1895). Розпочав будівництво Микола Федорович Мещерін, проте незабаром, ще до закінчення спорудження заводу, він перейшов на службу до підприємця Пастухова для будівництва Сулинського заводу. Фактично керманичем будівництва став інженер Іван Ілліч Зеленцов (1844-1910). У процесі спорудження Лисичанського чавуноливарного заводу вперше будівельні й експлуатаційні роботи здійснювалися без допомоги іноземних спеціалістів. Проєктування машин і механізмів для заводу доручили інженеру Івану Августовичу Тіме (1838-1920). Для доставки виготовлених на Луганському заводі машин до місця будівництва Лисичанського заводу І. Тіме разом з гірничим інженером М. Мещеріним використав пароплав, уперше застосувавши цей вид транспорту на Сіверському Дінці $[5,174]$.

Протягом 1868-1869 pp. І. Тіме провів досліди й безпосередні спостереження форм і способів утворення стружок за різних умов та на різних металах. Свої теоретичні узагальнення та висновки він виклав у праці «Сопротивление металлов и дерева резанью». Тут уперше у світовій науці викладена теорія утворення стружки $[4,250]$.

Помічником I. Тіме з металургійної частини на Лисичанському чавуноливарному заводі був інженер-металург І. Зеленцов. В історію Донецького басейну він увійшов як талановитий гірничий інженер, який зробив значний внесок у розвиток вітчизняної металургії, був одним із піонерів створення чорної металургії на Півдні України.

I. Зеленцов у 1864 р. закінчив Петербурзький інститут Корпусу гірничих інженерів 3 великою золотою медаллю та із занесенням його імені на золоту дошку навчального закладу. У наступні роки він захопився металургійною справою, без розвитку якої прогрес держави був неможливий. Для ознайомлення з технологією металургійного виробництва молодий спеціаліст чотири рази направлявся Гірничим департаментом у країни Західної Європи, які мали на той час розвинуте металургійне виробництво. Набутий досвід дозволив Івану Іллічу очолити у 1868 р. будівництво Лисичанського казенного металургійного заводу. Завдяки його зусиллям на цьому підприємстві вдалося вдосконалити технологію виплавки чавуну на мінеральному паливі, використавши досвід Петровського заводу. 
Перша доменна піч на Лисичанському заводі була задута 1 травня 1870 p. під керівництвом I. Зеленцова. Протягом семиденної безперервної роботи доменної печі виплавили майже 4 тис. пудів м'якого сірого чавуну, що не поступався за якістю англійському. Проте домогтися в широких масштабах економічно вигідної промислової виплавки металу на Лисичанському заводі не вдалося. Руду привозили за 60 верст і обходилася вона дорого. Кокс з лисичанського вугілля був неякісний. Через ці та інші причини підприємство у 1872 р. закрили $[14,120]$.

Лисичанський чавуноливарний завод мав велике значення для розвитку металургійної промисловості на Півдні України. Дослідна плавка довела, що в Донецькому басейні можливо отримувати чавун на мінеральному паливі з місцевих матеріалів. Високо оцінив досягнуті результати I. А. Тіме. Він писав, що «... чисто з технічної точки зору в Лисичанську справа плавки була посунута значно далі, аніж при попередніх спробах. Дослідною плавкою на Лисичанському заводі отримано за найнесприятливішими умовами відносно заготівлі сирих матеріалів близько 60 тис. пудів цілком доброго чавуну... Економічне фіаско... заводу... все-таки не віднімає історичного значення цього заводу, що поклав початок розвитку гірничозаводської справи на Півдні Росії» $[13,75]$.

Отже, інженерно-технічна інтелігенція відіграла значну роль у становленні та розвитку залізорудної і металургійної промисловості Півдня у перед- і післяреформений період. Інженери і техніки спрямовували свою діяльність на вдосконалення виробництва та вивчення надр промислового регіону України. Відкриті інженерами великі поклади залізних руд стали базою для бурхливого розвитку тут металургійної промисловості. Технічні нововведення, упроваджені за ініціативою інженерно-технічних працівників, сприяли зростанню продуктивності виробництва. Окрім виробничої діяльності, інженери займалися науковими дослідженнями, сприяючи розвитку теорії та практики гірничозаводської справи.

Розглянута тема має перспективи подальшого дослідження, зокрема в період кінця XIX - початку XX ст., коли відбувався бурхливий індустріальний розвиток Російської імперії, зокрема й України.

\section{Abstract}

The purpose of this article is to examine the professional activities of mining engineers and other specialists in the South of Ukraine in the modern period and to show their role in the formation and development of metallurgical industry.

Outstanding mining engineer A. F. Mevius devoted almost half a century of his life to the development of industry in the Donetsk basin. He worked for many years in the Lugansk mountain district, the chief of which was in 1861. Working on this post he's done a lot for the development of mining and metallurgical production in the Donbass. In 1860-e years supervised the construction of Ukraine's first puddling factories of Lugansk foundry. A. F. Mevius - one of the initiators of convocation of congresses of miners of the South of Russia, which has played a leading role in creating the 
industry of Donbass and the Dnieper. For 20 years he was the head of the Executive body of the Congress - by the Council, using the authority among mining professionals and Industrialists of the South.

Engineering-technical intelligentsia played a significant role in the formation and development of iron-ore and metallurgical industry of the South in the pre-and post-reform period. Engineers and technicians were focused on improving production and exploration in the industrial region of Ukraine. Open engineers with large deposits of iron ore became the basis for the rapid development of metallurgical industry. Technical innovations introduced at the initiative of the engineering and technical personnel, contributed to the growth of manufacturing productivity. In addition to the production activities of engineers engaged in scientific research, contributing to the development of the theory and practice of the mining business. The topic under consideration has prospects for further research, in particular in the period of late XIX-early XX centuries, when there was a rapid industrial development of the Russian Empire, including Ukraine.

Keywords: South of Ukraine, Donbass, iron ore industry, metallurgical industry, mining engineers.

\section{ДЖЕРЕЛА ТА ЛІТЕРАТУРА}

1. Довжук І. В. Апполон Федорович Мевіус. Бодрухин В. М., Романиов В. М. та ін. Історичні постаті України: проблеми і пошуки: монографія. Луганськ: Вид-во СНУ ім. В. Даля, 2003. С. 118-132.

2. Довжук I. В. Індустріальний Донбас в історії розвитку економіки Наддніпрянської України (друга половина XIX - початок XX ст.): монографія. Луганськ: вид-во СНУ ім. В. Даля, 2009. 364 с.

3. Иванов Н. А. О месторождениях железных руд в Екатеринославской губернии близ Лисичанска и исследовании состава этих руд, а также качеств каменноугольного кокса, флюсового известняка и огнепостоянной глины, устраиваемого при Лисичанском каменноугольном руднике чугуноплавильного завода. Горный журнал. 1868. № 8. С. 220-247.

4. Люди русской науки. Очерки о выдающихся деятелях естествознания и техники / под. ред. И. В. Кузнецова. Москва: Наука, 1965. 783 с.

5. Новик Е. О., Пермяков В. В., Коваленко Е. Е. История геологических исследований Донецкого каменноугольного бассейна (1700-1917). Киев: АН УССР, $1960.532 \mathrm{c}$.

6. Орловський Б. М. Залізорудна промисловість України в дореволюційний період: історико-економічний нарис. Київ: Наук. думка, 1974. 183 с.

7. Очерки истории техники в России с древнейших времен до 60-х годов XIX века / И. И. Артоболевский, А. С. Федоров, С. Я. Плоткин и др.; отв. ред. Вс. И. Остольский. Москва: Наука, 1978. 385 с.

8. Подов В. И., Курило В. С. Первенец металлургии Украины: Исторический очерк. Документы. Луганск: Світлиця, 1998. 216 с.

9. Развитие металлургии в Украинской ССР / Ю. А. Анисимов, Н. А. Терещенко, В. Г. Тищенко и др.; редкол.: З. И. Некрасов (отв. ред.) и др. Киев: Наукова думка, 1980. 959 с. 
10. Сапальский В. Ф. О месторождении железных руд в окрестностях вновь строящегося в Бахмутском уезде чугуноплавильного завода. Горный журнал. 1860. № 6. С. 471-494.

11. Сборник статистических сведений по горной части на 1867 год. С.-Петербург, 1867.

12. Середенко М. М. Чорна металургія України, 1917-1957 рр. Київ: Держтехвидав УРСР, 1957. 168 с.

13. Тиме И. А. Очерк современного состояния горнозаводского дела в Донецком бассейне. Горный журнал. 1889. Т. 1. С. 1-217.

14. Фелькнер И. Каменный уголь и железо в России. СПб., 1874. 175 с.

15. Фомин П. И. Горная и горнозаводская промышленность юга России: в 2 т. T. 1: История горной и горнозаводской промышленности юга России со времени возникновения до восьмидесятых годов прошлого века. Харьков, 1915. $391 \mathrm{c}$.

\section{References}

1. Dovzhuk, I. V. (2003). Appolon Fedorovych Mevius [Apollon Fedorovich Mevius]. Bodrukhyn V. M., Romantsov V. M. ta in. Istorychni postati Ukrainy: problemy i poshuky: monohrafiia. Luhansk: Vyd-vo SNU im. V. Dalia.

2. Dovzhuk, I. V. (2009). Industrialnyi Donbas v istorii rozvytku ekonomiky Naddniprianskoi Ukrainy (druha polovyna XIX - pochatok XX st.): monohrafiia [Industrial Donbass in the History of Economic Development of the Naddnipryansky Ukraine (second half of XIX - beginning of XX century): monograph]. Luhansk: vyd-vo SNU im. V. Dalia.

3. Ivanov, N. A. (1968). O mestorozhdenijah zheleznyh rud v Ekaterinoslavskoj gubernii bliz Lisichanska i issledovanii sostava jetih rud, a takzhe kachestv kamennougol'nogo koksa, fljusovogo izvestnjaka i ognepostojannoj gliny, ustraivaemogo pri Lisichanskom kamennougol'nom rudnike chugunoplavil'nogo zavoda [About iron ore deposits in the Yekaterinoslav province near Lysychansk and a study of the composition of these ores, as well as the qualities of coal coke, flux limestone and fire-resistant clay, arranged at the Lisichansk coal mine of an iron smelter]. Gornyj zhurnal, 8, 220-247.

4. Ljudi russkoj nauki. Ocherki o vydajushhihsja dejateljah estestvoznanija i tehniki [People of Russian science. Essays on prominent figures in science and technology] / pod. red. I. V. Kuznecova. Moskva: Nauka, 1965.

5. Novik, E. O., Permjakov, V. V., Kovalenko, E. E. (1960). Istorija geologicheskih issledovanij Doneckogo kamennougol'nogo bassejna (1700-1917) [History of geological exploration of the Donetsk coal basin (1700-1917)]. Kyiv: AN USSR. 
6. Orlovskyi, B. M. (1974). Zalizorudna promyslovist Ukrainy v dorevoliutsiinyi period: istoryko-ekonomichnyi narys [Iron-ore industry of Ukraine in the prerevolutionary period: historical and economic essay]. Kyiv: Nauk. dumka.

7. Ocherki istorii tehniki v Rossii s drevnejshih vremen do 60-h godov XIX veka [Essays on the history of technology in Russia from ancient times to the 60s of the 19th century] / Artobolevskij I. I., Fedorov A. S., Plotkin S. Ja. i dr.; otv. red. Vs. I. Ostol'skij. M.: Nauka, 1978.

8. Podov, V. I., Kurilo, V. S. (1998). Pervenec metallurgii Ukrainy: Istoricheskij ocherk. Dokumenty [First-born of metallurgy in Ukraine: Historical outline. Documents]. Lugansk: Svitlicja.

9. Razvitie metallurgii $\mathrm{v}$ Ukrainskoj SSR [The development of metallurgy in the Ukrainian SSR] / Ju. A. Anisimov, N. A. Tereshhenko, V. G. Tishhenko i dr.; redkol.: Z. I. Nekrasov (otv. red.) i dr. Kyiv: Naukova dumka, 1980.

10. Sapal'skij, V. F. (1860). O mestorozhdenii zheleznyh rud v okrestnostjah vnov' strojashhegosja v Bahmutskom uezde chugunoplavil'nogo zavoda [About the iron ore deposit in the vicinity of the newly-built iron smelter in Bakhmut district]. Gornyj zhurnal, 6, 471-494.

11. Sbornik statisticheskih svedenij po gornoj chasti na 1867 god [Collection of statistical information on the mountainous part for 1867]. St. Petersburg, 1867.

12. Seredenko, M. M. (1957). Chorna metalurhiia Ukrainy, 1917-1957 rr. [Ferrous metallurgy of Ukraine, 1917-1957]. Kyiv: Derzhtekhvydav URSR.

13. Time, I. A. (1889). Ocherk sovremennogo sostojanija gornozavodskogo dela v Doneckom bassejne [Essay on the current state of mining in the Donetsk basin]. Gornyj zhurnal, 1, 1-217.

14. Fel'kner, I. (1874). Kamennyj ugol' i zhelezo v Rossii [Coal and iron in Russia]. St. Petersburg.

15. Fomin, P. I. (1915). Gornaja i gornozavodskaja promyshlennost' juga Rossii: v 2 t. T. 1: Istorija gornoj i gornozavodskoj promyshlennosti juga Rossii so vremeni vozniknovenija do vos'midesjatyh godov proshlogo veka [Mining and mining industry in the south of Russia: in 2 volumes. T. 1: History of mining and mining industry in the south of Russia from the time of its origin until the eighties of the last century]. Har'kov. 